\title{
ПОРІВНЯННЯ ЕФЕКТИВНОСТІ МЕТОДІВ ОДЕРЖАННЯ ЛІКАРСЬКОЇ СУБСТАНЦЇ̈ 3 КОРЕНІВ ПЕЛАРГОНІЇ ОЧИТКОВОї (PELARGONIUM SIDOIDES)
}

\section{Брида О. Р., Стадницька Н. С.}

\section{ВСТУП}

Фітопрепарати набувають популярності на фармацевтичних ринках України та Європи ${ }^{1}$. Серед засобів для лікування захворювань верхніх дихальних шляхів, які викликають найбільшу зацікавленість у медиків та пацієнтів, є препарати, котрі володіють імуностимулюючими, вірусостатичними, антибактерійними, бактеріостатичними й антиоксидантними властивостями ${ }^{2}$.

Гострі інфекційні захворювання верхніх дихальних шляхів - це запальні процеси в носоглотці, викликані вірусами або бактеріями. Їх поділяють на захворювання верхніх дихальних шляхів - риніт, риносинусит, синусит, ринофарингіт, фарингіт, тонзиліт, отит, ларингіт та нижніх дихальних шляхів - трахеїт, бронхіт, пневмонія. Основним механізмом передачі захворювання $\epsilon$ повітрянокрапельний шлях, зрідка в деяких вірусів - фекально-оральний ${ }^{3}$.

Гострі респіраторні вірусні захворювання, які викликані риновірусом, $\epsilon$ найбільш контагіозними протягом перших трьох днів із моменту появи симптомів. Після того, як мине три дні, хвороба $\epsilon$ не такою заразною ${ }^{4}$.

Серед фітопрепаратів, які можна використовувати для профілактики захворювань верхніх дихальних шляхів, зокрема як у країнах Європи, так і України, Росії та Білорусії, є лікарські засоби із вмістом

${ }^{1}$ Сучасні рослинні засоби для лікування кашлю / О.Я. Міщенко та ін. 2020.

2 Перспектива створення комплексного препарату 3 рослинними екстрактами для терапії захворювань верхніх дихальних шляхів / О.А. Рубан та ін. 2020.

3 Інфекційні хвороби : підручник / О.А. Голубовська, М.А. Андрейчин, А.В. Шкурба та ін. ; за ред. О.А. Голубовської. Київ : ВСВ «Медицина». 2018. 688 с. +12 c. C. 236.

${ }^{4}$ Gwaltney JM Jr, Halstead SB. Contagiousness of the common cold. Invited letter in Questions and answers. Journal of the American Medical Association 278 (3): 256-257. 16 July 1997. 
водно-спиртового або сухого екстракту 3 пеларгонії очиткової (Pelargonium sidoides) $^{5,6}$.

\section{1. Морфологія, фітохімічний склад, біологічна дія пеларгонії очиткової Pelargonium sidoides}

Однією з лікарських рослин, що використовується для лікування захворювань верхніх дихальних шляхів, $\epsilon$ пеларгонія очиткова (Pelargonium sidoides) ${ }^{7,8}$. Пеларгонія очиткова (Pelargonium sidoides) - це багаторічна рослина, одна 3 250-ти видів рослин родини Геранієвих (Geraniaceae). Стебла прямі або повзучі, гіллясті. Листки прості, пальчасті або пальчасто-розсічені. Квітки мають від п'яти пелюсток від темно-червоного до майже чорного забарвлення, дві з яких майже завжди зростаються. Найбільший ареал поширення пеларгонії очиткової - у Південній Африці ${ }^{9}$.

Основними діючими речовинами у водно-спиртовому екстракті пеларгонії $є$ фенольні сполуки: кумарини, флавоноїди, фенольні кислоти. До групи кумаринів входять біологічно-активні речовини: скополетин, 5,6,7-триметоксикумарин, 6,8-дигідрокси-5,7-диметоксикумарин, які мають високу противірусну, антимікробну, імуномоделюючу та протизапальну активності ${ }^{10,11}$. Група флавоноїдів у пеларгонії очиткової представлена в основному істинними

${ }^{5}$ Brendler, T., \& Van Wyk, B. E. (2008). A historical, scientific and commercial perspective on the medicinal use of Pelargonium sidoides (Geraniaceae). Journal of ethnopharmacology. 119(3). P. 420-433. https://doi.org/10.1016/j.jep.2008.07.037.

${ }^{6}$ Michaelis, M., Doerr, H. W., \& Cinatl Jr, J. (2011). Investigation of the influence of EPs® 7630, a herbal drug preparation from Pelargonium sidoides, on replication of a broad panel of respiratory viruses. Phytomedicine. 18(5). P. 384-386. https://doi.org/10.1016/ j.phymed.2010.09.008.

Пріоритетність застосування фітопрепаратів у лікуванні вірусних респіраторних інфекцій у дітей / Т.О. Крючко та ін. Здоровье ребенка 2018. № 1(13). C. 28-34. DOI 10.22141/2224-0551.13.1.2018.127062.

${ }^{8}$ Brendler, T., \& Van Wyk, B. E. (2008). A historical, scientific and commercial perspective on the medicinal use of Pelargonium sidoides (Geraniaceae). Journal of ethnopharmacology, 119(3). P. 420-433. https://doi.org/10.1016/j.jep.2008.07.037.

${ }^{9}$ Lis-Balchin, Maria (2003). Geranium and Pelargonium: History of Nomenclature, Usage and Cultivation. Boca Raton, Florida: CRC. ISBN 978-0-203-21653-8.

${ }^{10}$ Conrad, A., Jung, I., Tioua, D., Lallemand, C., Carrapatoso, F., Engels, I., ... \& Frank, U. (2007). Extract of Pelargonium sidoides (EPs $® 7630)$ inhibits the interactions of group A-streptococci and host epithelia in vitro. Phytomedicine, 14, 52-59. https://doi.org/10.1016/j.phymed.2006.11.018.

${ }^{11}$ Kayser, O., \& Kolodziej, H. (1997). Antibacterial activity of extracts and constituents of Pelargonium sidoides and Pelargonium reniforme. Planta medica, 63(06), 508-510. DOI 10.1055/s-2006-957752. 
флавоноїдами: фланолами (катехін, афцелехін, галокатехін, кверцетин, кемпферол). Флавоноїди зумовлюють протизапальний, противірусний, антиоксидантний ефекти ${ }^{12}$.

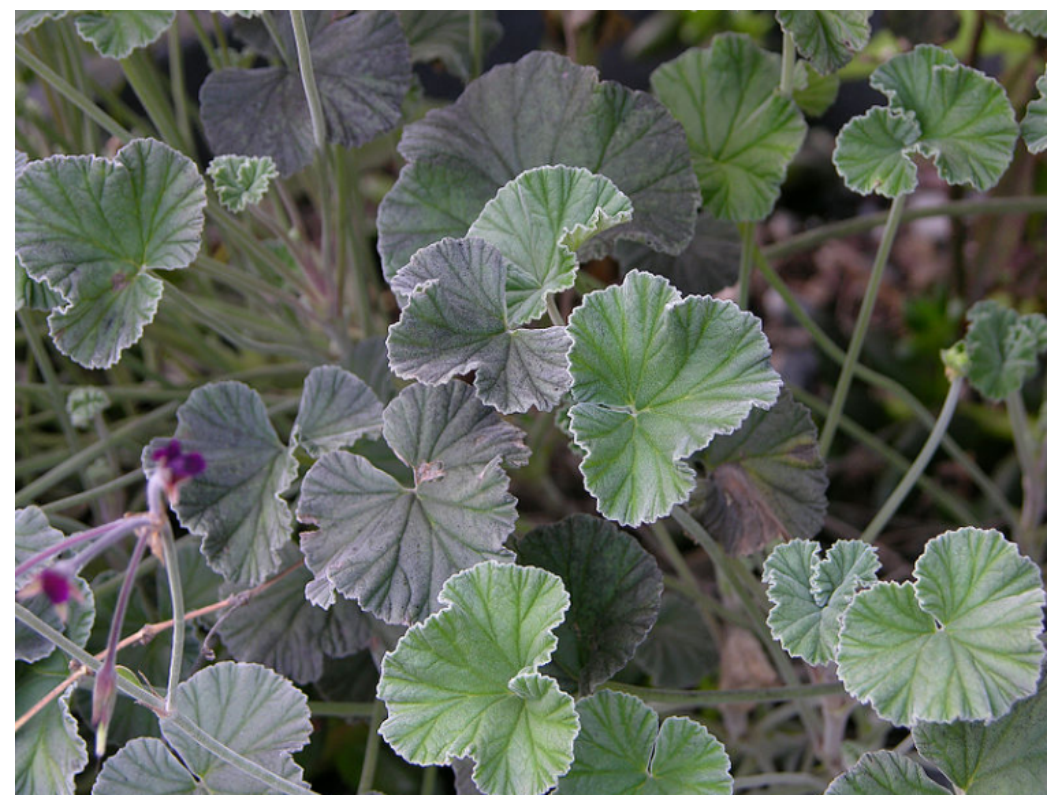

Рис. 1. Зображення пеларгонії очиткової

Photo by and (c)2006 Derek Ramsey (Ram-Man). Location credit to the Chanticleer Garden. - Self-photographed

Протизапальна дія зумовлена здатністю гальмувати утворення медіаторів запалення ${ }^{13}$, простагландинів, лейкотриєнів та оксиду азоту. Імуномодулююча дія зумовлена активацією ряду клітин базофілів, нейтрофілів, еозинофілів, Т-лімфоцитів, макрофагів, гепатоцитів тощо. Антимікробний ефект пов'язаний 3 наявністю кверцитину, який має також антиоксидантний, мембраностабілі-

${ }^{12}$ Kayser, O., Kolodziej, H., \& Kiderlen, A. F. (2001). Immunomodulatory principles of Pelargonium sidoides. Phytotherapy Research, 15(2), 122-126. https://doi.org/10.1002/ ptr.785.

${ }^{13}$ Agbabiaka, T. B., Guo, R., \& Ernst, E. (2008). Pelargonium sidoides for acute bronchitis: a systematic review and meta-analysis. Phytomedicine, 15(5), 378-385. https://doi.org/10.1016/j.phymed.2007.11.023. 
зуючий, капіляростабілізуючий, кардіопротекторний, регенеративний та спазмолітичний ефекти ${ }^{14,15,16}$. Доведено наявність антимікробної дії кверцитину на Bacillus cereus, Salmonella enteritidis та Staphilococcus aureus. В екстракті пеларгонії очиткової також $\epsilon$ фенолокислоти, представлені галовою кислотою та іiі метиловим ефіром, які мають високі антиоксидантні властивості. Галова кислота володіє можливостями індукувати синтез оксиду азоту, який у свою чергу активує макрофагів, потенціює синтез інтерферону клітинами, внаслідок чого неінфіковані клітини стають захищеними від вірусної інфекції ${ }^{17,18,19,20}$.

Ефективність використання екстракту лікарських препаратів на основі екстракту пеларгонії очиткової (Pelargonium sidoides) продемонстровано в низці клінічних досліджень ${ }^{21}$. Також $\epsilon$

${ }^{14}$ Jekabsone, A., Sile, I., Cochis, A., Makrecka-Kuka, M., Laucaityte, G., Makarova, E., ... \& Baniene, R. (2019). Investigation of antibacterial and antiinflammatory activities of proanthocyanidins from pelargonium sidoides DC root extract. Nutrients, 11(11), 2829. https://doi.org/10.3390/nu11112829.

${ }^{15}$ Tahan F, Yaman M. (2013). Can the Pelargonium sidoides root extract EPs ${ }^{\circledR} 7630$ prevent asthma attacks during viral infections of the upper respiratory tract in children? Phytomedicine. 20(2):148-150. https://doi.org/10.1016/j.phymed.2012.09.022.

${ }^{16}$ Kolodziej, H., \& Kiderlen, A. F. (2007). In vitro evaluation of antibacterial and immunomodulatory activities of Pelargonium reniforme, Pelargonium sidoides and the related herbal drug preparation $\operatorname{EPS}{ }^{\circledR}$ 7630. Phytomedicine, 14, 18-26. https://doi.org/ 10.1016/j.phymed.2006.11.020.

${ }^{17}$ Timmer A, Gunther J, Motschall E et al. (2013). Pelargonium Sidoides extract for treating acute respiratory tract infections. Cochrane Database of Systematic Rev;10:CD006323. https://doi.org/10.1002/14651858.CD006323.pub3.

${ }^{18}$ Kolodziej H., Kayser O., Radtke O. A., Kiderlen A. F., \& Koch E. (2003). Pharmacological profile of extracts of Pelargonium sidoides and their constituents. Phytomedicine, 10, 18-24. https://doi.org/10.1078/1433-187X-00307.

${ }^{19}$ Mativandlela, S. P. N., Lall, N., \& Meyer, J. J. M. (2006). Antibacterial, antifungal and antitubercular activity of (the roots of) Pelargonium reniforme (CURT) and Pelargonium sidoides (DC)(Geraniaceae) root extracts. South African Journal of Botany, 72(2), 232-237. https://doi.org/10.1016/j.sajb.2005.08.002.

${ }^{20}$ Michaelis, M., Doerr, H. W., \& Cinatl Jr, J. (2011). Investigation of the influence of EPs ${ }^{\circledR} 7630$, a herbal drug preparation from Pelargonium sidoides, on replication of a broad panel of respiratory viruses. Phytomedicine, 18(5), 384-386. https://doi.org/ 10.1016/j.phymed.2010.09.008.

${ }^{21}$ Lizogub, V. G., Riley, D. S., \& Heger, M. (2007). Efficacy of a pelargonium sidoides preparation in patients with the common cold: a randomized, double blind, placebo-controlled clinical trial. Explore, 3(6), 573-584. https://doi.org/10.1016/ j.explore.2007.09.004. 
підтвердження, що ці препарати безпечні для використання дітям $^{22,23,24}$.

Українські фармацевтичні вітчизняні фірми, такі як ПАТ «Галичфарм», ТОВ «Тернофарм», ТОВ «Мультіспрей», ТОВ «Юрія-Фарм», ПАТ «Фармак», ПАТ Фармацевтична фірма «Дарниця», ТДВ «Інтерхім», ТОВ «Мікрофарм», ТОВ Фармацевтична компанія «Здоров’я», «Борщагівський ХФЗ», ПАТ «Київмедпрепарат», ПАТ Хімфармзавод «Червона зірка», ТОВ «НІКО» та інші випускають лікарські засоби як синтетичного походження, так i на основі рослинної сировини для лікування захворювань дихальної системи. На фармацевтичному ринку України станом на грудень 2020 року наявні такі лікарські засоби на основі субстанцій iз коренів пеларгонії очиткової: «Резістол» (ПАТ «Галичфарм», Україна) ${ }^{25,26}$, «Папалор» (Фітофарм Кленка С.А., Польща) ${ }^{27}$, «Пелорсін» (АТ «Фармак», Україна), «Умкалор» (Др. Вільмар Швабе ГмбХ і Ко. КГ, Німеччина) $28,29,30$, «Пелафен» (Вівелгув ГмбХ, Німеччина).

${ }^{22}$ Bachert C., Schapowal A., Funk P., \& Kieser M. (2009). Treatment of acute rhinosinusitis with the preparation from Pelargonium sidoides EPs 7630: a randomized, double-blind, placebo-controlled trial. Rhinology, 47(1), 51.

${ }^{23}$ Matthys, H., Kamin, W., Funk, P., \& Heger, M. (2007). Pelargonium sidoides preparation (EPs ${ }^{\circ}$ 7630) in the treatment of acute bronchitis in adults and children. Phytomedicine, 14, 69-73. https://doi.org/10.1016/j.phymed.2006.11.015.

${ }^{24}$ Бережний В.В. Гострі респіраторні захворювання у дітей: ранній стартовий підхід до терапії. Доказова база даних (огляд). Современная педиатрия. 2019. № 1. C. 89-101. DOI 10.15574/SP.2019.97.89.

25 Вплив лікарського засобу Резістол® на гуморальний та клітинний імунітет дітей з рекурентними та гострими вірусними респіраторними захворюваннями: результати дослідження / Л.В. Квашніна та ін. Современная педиатрия. 2018. № 8. C. 104-113. DOI 10.15574/SP.2018.96.104.

${ }^{26}$ Опыт использования препарата Резистол в комплексном лечении пациентов с острым бронхитом / М.Н. Селюк и др. Семейная медицина. 2015. № 3. С. 201-201.

27 Мироник, О.В., Давиденко О.М., Фельдман Л.Я. Клінічна ефективність препарату «Папалор» у комплексному лікуванні хворих на ангіни / Pridneprovskiy scientific bulletin. 2015. № 40(456). URL: http://rusnauka.com/index.php/rusnauka/ article/view/22306

28 Черных В.П., Георгиянц В.А., Зупанец И.А. Клинико-фармацевтические аспекты применения фитопрепарата «Умкалор». Журнал вушних, носових і горлових хвороб. 2003. № 3. С. 74-83.

29 Ёлкина Т.Н, Грибанова О.А. Монотерапия острых респираторных инфекций препаратом «Умкалор». РМЖ. 2008. № 16(29):1968.

${ }^{30}$ Косаківський А.А, Безшапочний С.Б. Прогнозування «Умкалор» та «Цинабсин» при лікуванні хворих на гострий риносинуіт. ЖУНГ. 2010. № 6. С. 10-12. 
Таблиця 1

Препарати із вмістом екстракту коренів пеларгонії очиткової

\begin{tabular}{|c|c|c|c|}
\hline Назва & $\begin{array}{c}\text { Лікарська } \\
\text { форма }\end{array}$ & Виробник & Заявник \\
\hline ПАПАЛОР & $\begin{array}{l}\text { краплі } \\
\text { оральні }\end{array}$ & $\begin{array}{c}\text { Фітофарм } \\
\text { Кленка С.А., Польща }\end{array}$ & $\begin{array}{c}\text { ТОВ «Ерсель } \\
\text { Фарма Україна», } \\
\text { Україна }\end{array}$ \\
\hline УМКАЛОР® & $\begin{array}{c}\text { розчин } \\
\text { оральний }\end{array}$ & $\begin{array}{c}\text { Др. Вільмар Швабе } \\
\text { ГмбХ і Ко. КГ, } \\
\text { Німеччина }\end{array}$ & $\begin{array}{c}\text { Дойче Хомеопаті- } \\
\text { Уніон ДХУ- } \\
\text { Арцнайміттель } \\
\text { ГмбХ \& Ко. КГ, } \\
\text { Німеччина } \\
\end{array}$ \\
\hline ПЕЛОРСІН®, & $\begin{array}{l}\text { таблетки, } \\
\text { вкриті } \\
\text { плівковою } \\
\text { оболонкою } \\
\end{array}$ & $\begin{array}{c}\text { АТ «Фармак», } \\
\text { Україна }\end{array}$ & $\begin{array}{c}\text { АТ «Фармак», } \\
\text { Україна }\end{array}$ \\
\hline УМКАЛОР®, & $\begin{array}{c}\text { таблетки, } \\
\text { вкриті } \\
\text { плівковою } \\
\text { оболонкою }\end{array}$ & $\begin{array}{c}\text { Др. Вільмар Швабе } \\
\text { ГмбХ і Ко. КГ, } \\
\text { Німеччина }\end{array}$ & $\begin{array}{c}\text { Др. Вільмар Швабе } \\
\text { ГмбХ і Ко. КГ, } \\
\text { Німеччина }\end{array}$ \\
\hline ПЕЛАФЕН & $\begin{array}{c}\text { таблетки, } \\
\text { вкриті } \\
\text { оболонкою }\end{array}$ & $\begin{array}{l}\text { Вівелгув ГмбХ, } \\
\text { Німеччина }\end{array}$ & $\begin{array}{c}\text { Фітофарм Кленка } \\
\text { С. А., Польща }\end{array}$ \\
\hline ПЕЛОРСІН & $\begin{array}{c}\text { розчин } \\
\text { оральний }\end{array}$ & $\begin{array}{c}\text { АТ «Фармак», } \\
\text { Україна }\end{array}$ & $\begin{array}{c}\text { АТ «Фармак», } \\
\text { Україна }\end{array}$ \\
\hline ПЕЛОРСІН® & сироп & $\begin{array}{c}\text { АТ «Фармак», } \\
\text { Україна }\end{array}$ & $\begin{array}{c}\text { АТ «Фармак», } \\
\text { Україна }\end{array}$ \\
\hline УМКАЛОР® & сироп & $\begin{array}{c}\text { Др. Вільмар Швабе } \\
\text { ГмбХ і Ко. КГ } \\
\text { (виробництво } \\
\text { продукції in bulk, } \\
\text { первинне та вторинне } \\
\text { пакування, контроль } \\
\text { якості та випуск } \\
\text { серій), Німеччина } \\
\end{array}$ & $\begin{array}{c}\text { Др. Вільмар Швабе } \\
\text { ГмбХ і Ко. КГ, } \\
\text { Німеччина }\end{array}$ \\
\hline РЕЗІСТОЛ® & $\begin{array}{c}\text { краплі } \\
\text { оральні }\end{array}$ & $\begin{array}{c}\text { ПАТ «Галичфарм», } \\
\text { Україна } \\
\end{array}$ & $\begin{array}{c}\text { ПАТ «Галичфарм», } \\
\text { Україна }\end{array}$ \\
\hline
\end{tabular}

Згідно 3 даними, представленими в таблиці 1, можна зробити висновок, що найбільше лікарських засобів на основі водноспиртового екстракту пеларгонії очиткової (Pelargonium sidoides) зустрічається у вигляді крапель або розчину орального (понад $44,4 \%$ ); значну частину асортименту досліджених препаратів 
становлять таблетовані лікарські форми на основі сухого екстракту пеларгонії очиткової (близько 33,3\%), лікарські препарати у формі сиропів для дітей становлять (приблизно $22,2 \%)^{31}$.

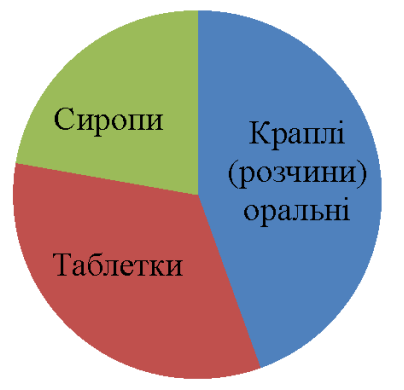

Рис. 2. Частка відповідних лікарських форм препаратів із вмістом субстанцій пеларгонії очиткової

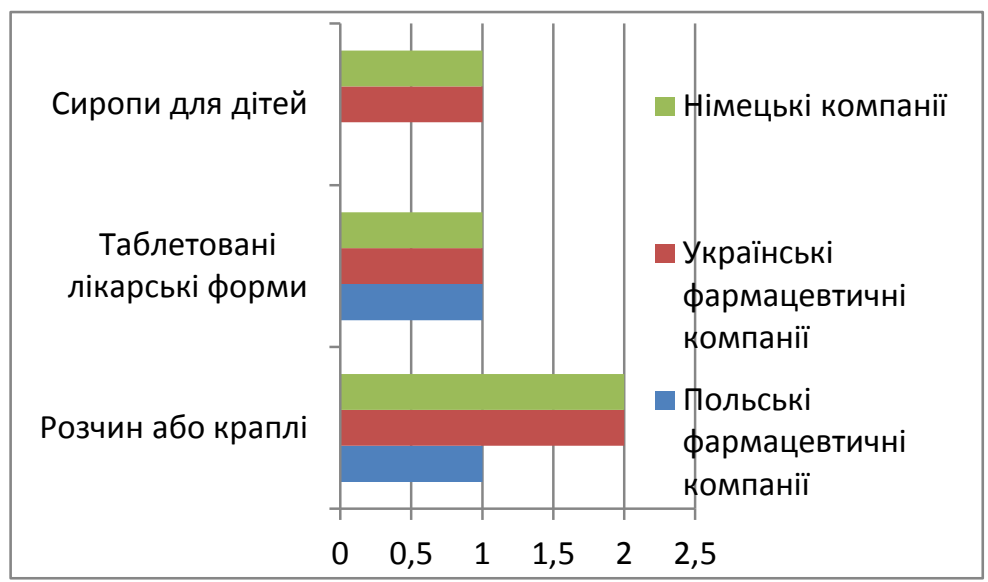

Рис. 3. Кількість лікарських форм, що випускають українські, німецькі та польські фармацевтичні компанії

Як можна помітити 3 рисунку 3, українські фармацевтичні компанії нічим не поступаються європейським у фармацевтичному розробленні різноманітних лікарських форм з метою максимального охоплення ринку.

\footnotetext{
31 Сайт Державної реєстрації лікарських засобів України. URL: http://www.drlz. com.ua/
} 


\section{2. Отримання екстракту коренів пеларгонії очиткової різними методами}

\section{Метод настоювання (мацераціï)}

Для отримання екстракту кореня пеларгонії очиткової методом настоювання (мацераціі) нами було використано лабораторний екстрактор, який представлений на рисунку 4.

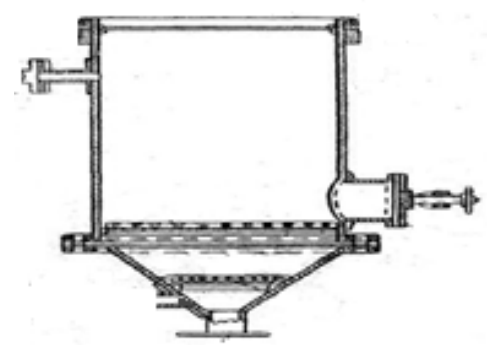

Рис. 4. Схема лабораторного екстрактора для мацерації

Для одержання екстракту пеларгонії очиткової (Pelargonium sidoides) було використано подрібнене коріння із вмістом вологи $12 \%$ та розміром частинок не більше 5 мм (згідно із ситовим аналізом), яке завантажували в екстрактор. Маса завантажувальної сировини становила 400 г.

Як екстрагент використовували спиртово-водну суміш із вмістом етанолу 12\% у співвідношенні сировина:екстрагент 1:12. Екстрагування проводили впродовж 64-х годин, 3 періодичним відбором проб через $1,2,4,8,16,24$ 32, 48, 64 год. від початку процесу настоювання.

Визначення сухого залишку проводили за фармакопейною статтею ДФУ2.8.16 ${ }^{32}$. Кожну пробу в кількості 2,0 мл екстракту поміщали в бюкс заввишки 30 мм та упарювали на водяній бані. Потім висушували в сушильній шафі за температури біля $100^{\circ} \mathrm{C}$ протягом 3 год., а тоді охолоджували в ексикаторі над шаром кальцій хлориду. Отримані результати представлено на рисунку 5 у вигляді кривих залежності кількості сухого залишку (мг/мл) від часу відбору проб (год.) та в таблиці 2.

32 Державна фармакопея України. Вид. 2-ге, перероб. та доп. Харків: Вид-во «Державне підприємство «Український науковий фармакопейний центр якості лікарських засобів», 2011. 540 с. 
Таблиця 2

Залежність виходу сухого залишку від часу екстрагування методом настоювання (мацерації)

\begin{tabular}{|c|c|c|c|}
\hline $\begin{array}{c}\text { Номер } \\
\text { проби }\end{array}$ & $\begin{array}{c}\text { Час відбору } \\
\text { проби, год. }\end{array}$ & Вміст сухого залишку мг/мл & $\begin{array}{c}\text { Вміст } \\
\text { танінів, \% }\end{array}$ \\
\hline 1 & 1 & 0,2 & 0,01 \\
\hline 2 & 2 & 0,6 & 0,02 \\
\hline 3 & 4 & 0,8 & 0,022 \\
\hline 4 & 8 & 1 & 0,032 \\
\hline 5 & 12 & 1,3 & 0,035 \\
\hline 6 & 16 & 1,4 & 0,055 \\
\hline 7 & 24 & 1,5 & 0,06 \\
\hline 8 & 32 & 1,5 & 0,065 \\
\hline 9 & 48 & 1,6 & 0,07 \\
\hline 10 & 64 & 1,6 & 0,07 \\
\hline
\end{tabular}

Для визначення вмісту танінів у екстрактах використовували стандартну методику, згідно з якою з кожної проби відбирали 10 мл і доводили водою очищеною до 250 мл, після чого фільтрували. Перші 50 мл фільтрату виливали. 3 решти фільтрату відбирали 5 мл і доводили до об'єму 25 мл водою очищеною. Суміш 2,0 мл отриманого розчину, 1,0 мл фосфорно-молібденово-вольфрамового реактиву i 10,0 мл води доводили розчином 290 г/л натрію карбонату до об’ єму 25,0 мл та вимірювали оптичну густину.

Стандартний розчин готували, розчиняючи у воді 50,0 мг пірогалолу, і доводили об'єм розчину одержаним екстрактом до 100,0 мл. 5,0 мл отриманого розчину доводили водою до об'єму 100,0 мл. Оптичну густину стандартного і досліджуваних розчинів вимірювали через 30 хвилин після приготування за довжини хвилі 760 нм, використовуючи як компенсаційний розчин воду. (ДФУ 2.2.25). Вміст танінів у відсотках розраховували за формулою:

$$
X=\frac{A_{1} m_{0} 62,5}{A_{2} m_{1}}
$$

де $\mathrm{m}_{0}$ - маса пірогалолу, в грамах; $\mathrm{m}_{1}$ - маса досліджуваної наважки, в грамах; $\mathrm{A}_{1}$ - оптична густина досліджуваного розчину; $\mathrm{A}_{2}$ - оптична густина стандартного розчину. 


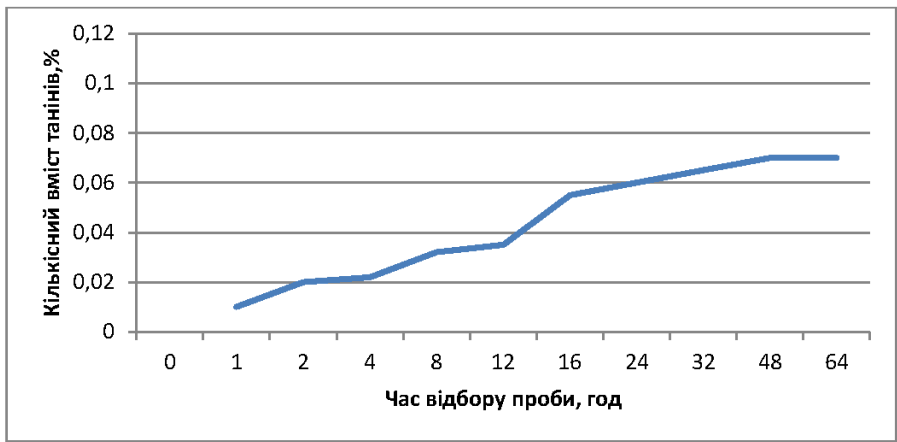

Рис. 5. Залежності вмісту сухого залишку від часу екстрагування за екстракції методом мацерації

Вміст танінів у одержаних пробах наведено в таблиці 3 . На рисунку 6 зображено залежність виходу танінів від часу екстрагування.

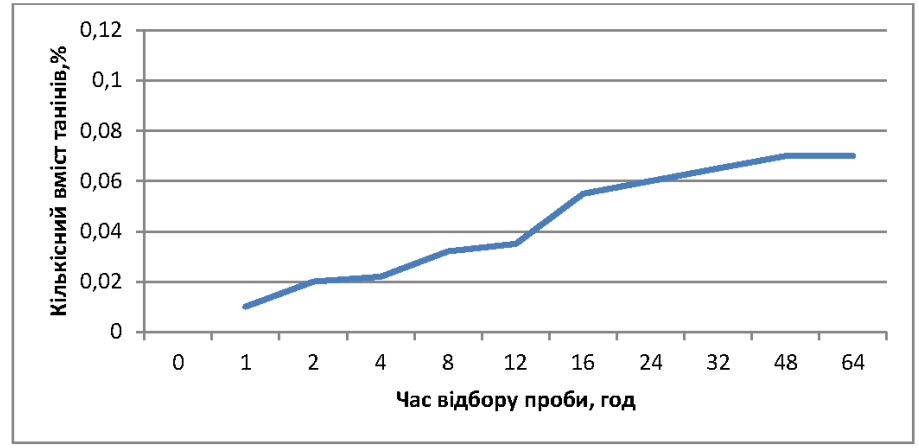

Рис. 6. Залежності вмісту танінів від часу екстрагування методом мацерації

У результаті екстрагування одержували кількість екстракту, що відповідає відношенню сировина:одержаний екстракт (DER), як $1: 8,115$.

Циркуляційна екстракція 3 кінцевим пресуванням реакційного середовища

Для отримання екстракту кореня пеларгонії очиткової використовували метод циркуляційної екстракції 3 кінцевим пресуванням реакційного середовища. 
Експеримент проводили 3 використанням класичного лабораторного екстрактора з використанням циркуляційного насосу 3 продуктивністю 8 л/год та з пресуючим елементом рис. 7.

Як і в попередньому експерименті, для одержання екстракту пеларгонії очиткової (Pelargonium sidoides) використовували подрібнене коріння із вмістом вологи $12 \%$. Сировину просіювали, щоб розмір частинок не перебільшував 5 мм, завантажували в кількості 400 г в екстрактор, заливали водно-спиртовою сумішшю у співвідношенні сировина:екстрагент 1:12. Екстрагування проводили впродовж 64-х годин, з увімкненим циркуляційним насосом, що забезпечував постійну циркуляцію екстракту крізь шар сировини.

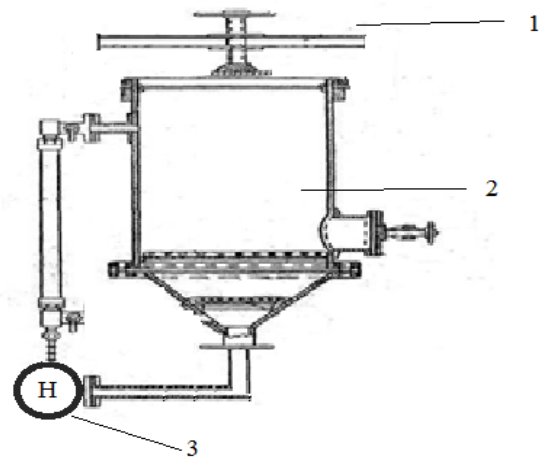

Рис. 7. Залежності вмісту танінів від часу екстрагування методом мацерації

1 - Пресувальний елемент; 2 - Корпус екстрактора (аналогічний класичній мачерачіï); 3 - Циркуляиійний насос

Таблиця 3

Залежність виходу сухого залишку від часу екстрагування методом циркуляційної екстракції з кінцевим пресуванням реакційного середовища

\begin{tabular}{|c|c|c|c|}
\hline $\begin{array}{c}\text { Номер } \\
\text { проби }\end{array}$ & $\begin{array}{c}\text { Час відбору } \\
\text { проби, год }\end{array}$ & $\begin{array}{c}\text { Вміст сухого залишку } \\
\text { мг/мл }\end{array}$ & $\begin{array}{c}\text { Вміст } \\
\text { танінів, \% }\end{array}$ \\
\hline 1 & 1 & 0,5 & 0,02 \\
\hline 2 & 2 & 1 & 0,03 \\
\hline 3 & 4 & 1,2 & 0,04 \\
\hline 4 & 8 & 1,69 & 0,1 \\
\hline 5 & 12 & 1,69 & 0,11 \\
\hline 6 & 16 & 1,68 & 0,13 \\
\hline 7 & 24 & 1,66 & 0,14 \\
\hline
\end{tabular}


Продовження таблиці 3

\begin{tabular}{|c|c|c|c|}
\hline 8 & 32 & 1,67 & 0,13 \\
\hline 9 & 48 & 1,65 & 0,13 \\
\hline 10 & 64 & 1,65 & 0,13 \\
\hline
\end{tabular}

Періодично проводився відбір проб аналогічно до попереднього періоду через 1, 2, 4, 8, 16, 24 32, 48, 64 год. від початку процесу екстрагування. Визначення сухого залишку й танінів проводили, як описано вище. Отримані результати представлено в таблиці 3 i на рисунках 8 i 9.

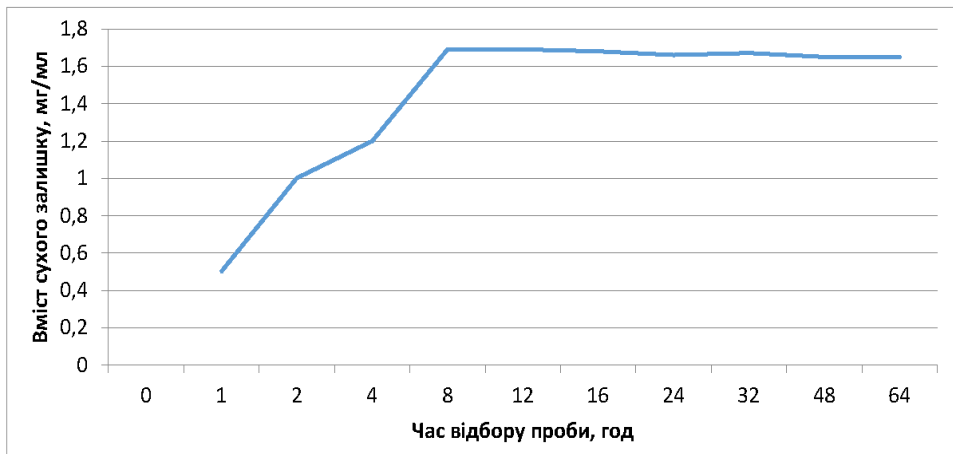

Рис. 8. Залежності вмісту сухого залишку від часу екстрагування методом циркуляційної екстракції 3 кінцевим пресуванням реакційного середовища

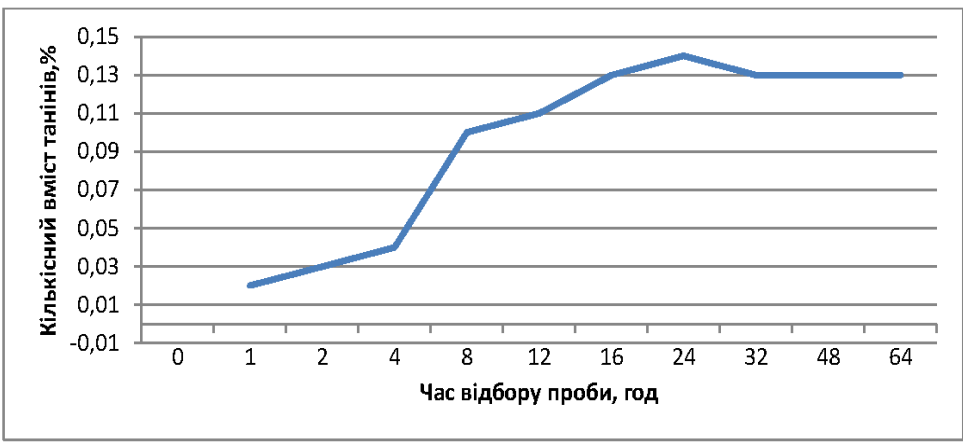

Рис. 9. Залежності вмісту танінів від часу екстрагування методом циркуляційної екстракції з кінцевим пресуванням реакційного середовища 


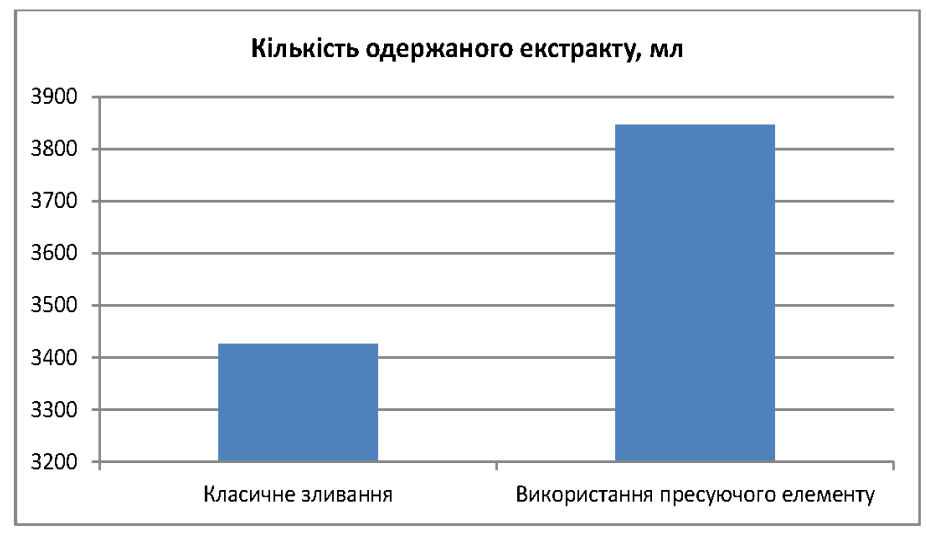

Рис. 10. Порівняння кількості одержання екстракту класичним зливанням та 3 використанням пресуючого елементу

Кінцевим продуктом ми одержали екстракт у кількості, що відповідає відношенню сировина:одержаний екстракт (DER), як $1: 9,6125$. Як видно 3 рисунку 10 , використання пресуючого елементу значно підвищило вихід кінцевого продукту.

Висновки. У нашому досліджені представлено результати порівняння ефективності методу одержання субстанції 3 коренів пеларгонії очиткової (Pelargonium sidoides). Досліджувальний екстракт використовують для виготовлення препаратів при захворюваннях дихальної системи. На ринку України наявні такі препарати 3 екстракту пеларгонії очиткової: «Резістол» (ПАТ «Галичфарм», Україна), «Папалор» (Фітофарм Кленка С.А., Польща), «Пелорсін» (АТ «Фармак», Україна), «Умкалор» (Др. Вільмар Швабе ГмбХ і Ко. КГ, Німеччина), «Пелафен» (Вівелгув ГмбХ, Німеччина).

Екстрагування кореня пеларгонії очиткової методом циркуляційної екстракції з кінцевим пресуванням реакційного середовища $\epsilon$ набагато ефективнішим способом одержання субстанції (активного фармацевтичного інгредієнта), ніж традиційний метод екстракції. За допомогою пресуючого елементу ми змогли одержати на 599 мл, або на 18,45\% готового екстракту більше, ніж за використання традиційної мацерації. Це пояснюється тим, що сировина коренів $є$ досить гігроскопічною, внаслідок чого втягує значну кількість екстракту в себе, а за рахунок пресування досягається повніше вилучення екстракту. 
За порівняння отриманих результатів максимальне значення за показником «Сухий залишок» в екстракті кореня пеларгонії очиткової сягає на 8-ій годині в разі застосування екстрагування методом циркуляційної екстракції, а в разі застосування традиційного методу екстракції - мацерації - максимальне значення за показником «Сухий залишок» проявляється тільки на 48-у годину.

Вміст танінів за динамічного методу екстрагування $є$ вищим протягом усього часу проведення процесу.

На основі отриманих результатів можна стверджувати, що метод циркуляційної екстракції 3 кінцевим пресуванням реакційного середовища дозволяє одержати більшу кількість екстракту з вищим вмістом екстрактивних речовин за коротший час екстракції. Це дозволяє раціональніше використовувати рідкісну рослинну сировину, суттєво підвищити якість одержаного екстракту пеларгонії очиткової (Pelargonium sidoides), а також зменшити тривалість його виготовлення. Використання цього методу екстракту може здешевити готовий препарат, що, очевидно, відобразиться на попиті споживачів.

\section{АНОТАЦІЯ}

У нашому дослідженні показано актуальність виготовлення лікарських засобів із вмістом екстракту коренів пеларгонії очиткової Pelargonium sidoides, що одержують методом циркуляційної екстракції 3 кінцевим пресуванням реакційного середовища. Запропонований метод порівнювали із традиційним методом екстрагування - мацерацією із простим злиттям екстракту. Препарати із вмістом цього екстракту використовуються для профілактики та лікування захворювань дихальної системи.

Сучасний ринок фітопрепаратів потребує одержання максимально економічно вигідних продуктів з лікарської рослинної сировини. Нашою метою було отримати екстракт, що відповідав би таким вимогам. Нами одержано більшу кількість екстракту з вищим вмістом екстрактивних речовин за меншу тривалість часу екстракції за допомогою методу циркуляційної екстракції 3 кінцевим пресуванням реакційного середовища.

Досліджувані зразки, одержані за рівні проміжки часу, порівнювали спочатку за показником «Сухий залишок», який визначали фармакопейним методом. Максимального значення цього показника в екстракті кореня пеларгонії очиткової досягнуто за 8 годин за використання методом циркуляційної екстракції 
3 кінцевим пресуванням реакційного середовища, натомість під час екстракції методом традиційної мацерації одержано набагато гірші показники, а саме «плато» досягнуто за 48 годин. Одержані зразки також досліджувались на визначення кількісного вмісту танінів. Вихід танінів стабілізувався в 6 раз скоріше за використання методом циркуляційної екстракції 3 кінцевим пресуванням реакційного середовища, ніж за традиційної екстракції методом настоювання (мацерації). Загальний вихід екстракту в разі застосування пресування збільшився на $18,45 \%$.

\section{ЛІТЕРАТУРА}

1. Сучасні рослинні засоби для лікування кашлю / О.Я. Міщенко та ін. 2020.

2. Перспектива створення комплексного препарату з рослинними екстрактами для терапії захворювань верхніх дихальних шляхів / О.А. Рубан та ін. 2020.

3. Інфекційні хвороби : підручник / О.А. Голубовська та ін. ; за ред. О.А. Голубовської. 2-ге видання, доповнене і перероблене. Київ : ВСВ «Медицина», 2018. 688 с. С. 236.

4. Gwaltney J.M. Jr, Halstead S.B. Contagiousness of the common cold. Invited letter in Questions and answers. Journal of the American Medical Association. 1997. 16 July. 278 (3): 256-257.

5. Brendler T., Van Wyk, B.E. A historical, scientific and commercial perspective on the medicinal use of Pelargonium sidoides (Geraniaceae). Journal of ethnopharmacology. 2008. 119 (3). 420-433. URL: https://doi.org/10.1016/j.jep.2008.07.037.

6. Michaelis M., Doerr H.W., Cinatl Jr J. Investigation of the influence of EPs ${ }^{\circledR} 7630$, a herbal drug preparation from Pelargonium sidoides, on replication of a broad panel of respiratory viruses. Phytomedicine. 2011. 18 (5). 384-386. URL: https://doi.org/10.1016/ j.phymed.2010.09.008.

7. Пріоритетність застосування фітопрепаратів у лікуванні вірусних респіраторних інфекцій у дітей. Здоровье ребенка / T.О. Крючко та ін. 2018. 13. № 1. С. 28-34. DOI 10.22141/22240551.13.1.2018.127062.

8. Brendler T., Van Wyk B.E. A historical, scientific and commercial perspective on the medicinal use of Pelargonium sidoides (Geraniaceae). Journal of ethnopharmacology. 2008. 119 (3). 420-433. URL: https://doi.org/10.1016/j.jep.2008.07.037. 
9. Lis-Balchin Maria. Geranium and Pelargonium: History of Nomenclature, Usage and Cultivation. Boca Raton, 2003. Florida : CRC. ISBN 978-0-203-21653-8.

10. Extract of Pelargonium sidoides (EPs $\AA$ 7630) inhibits the interactions of group A-streptococci and host epithelia in vitro. Phytomedicine / A. Contad et al. 2007. 14. 52-59. URL: https://doi.org/ 10.1016/j.phymed.2006.11.018.

11. Kayser O., Kolodziej H. Antibacterial activity of extracts and constituents of Pelargonium sidoides and Pelargonium reniforme. Planta medica. 1997. 63 (06). 508-510. DOI: 10.1055/s-2006-957752.

12. Kayser O., Kolodziej H., Kiderlen A.F. Immunomodulatory principles of Pelargonium sidoides. Phytotherapy Research. 2001. 15 (2). 122-126. URL: https://doi.org/10.1002/ptr.785.

13. Agbabiaka T.B., Guo R., Ernst E. Pelargonium sidoides for acute bronchitis: a systematic review and meta-analysis. Phytomedicine. 2008. 15 (5). 378-385. URL: https://doi.org/10.1016/j.phymed.2007.11.023.

14. Investigation of antibacterial and antiinflammatory activities of proanthocyanidins from pelargonium sidoides DC root extract. Nutrients / A. Jekabsone et al. 2019. 11 (11). 2829. URL: https://doi.org/ 10.3390/nu11112829.

15. Tahan F., Yaman M. Can the Pelargonium sidoides root extract EPs ${ }^{\circledR} 7630$ prevent asthma attacks during viral infections of the upper respiratory tract in children? Phytomedicine. 2013. 20 (2). 148-150. URL: https://doi.org/10.1016/j.phymed.2012.09.022.

16. Kolodziej H., Kiderlen A.F. In vitro evaluation of antibacterial and immunomodulatory activities of Pelargonium reniforme, Pelargonium sidoides and the related herbal drug preparation EPs ${ }^{\circledR}$ 7630. Phytomedicine. 2007. 14. 18-26. URL: https://doi.org/ 10.1016/j.phymed.2006.11.020.

17. Pelargonium Sidoides extract for treating acute respiratory tract infections. Cochrane Database of Systematic Rev;10:CD006323 / A. Timmer et al. 2013. URL: https://doi.org/10.1002/14651858. CD006323.pub3.

18. Pharmacological profile of extracts of Pelargonium sidoides and their constituents. Phytomedicine / H. Kolodziej et al. 2003. 10. 18-24. URL: https://doi.org/10.1078/1433-187X-00307.

19. Mativandlela S.P.N., Lall N., Meyer J.J.M. Antibacterial, antifungal and antitubercular activity of (the roots of) Pelargonium reniforme (CURT) and Pelargonium sidoides (DC)(Geraniaceae) root extracts. South African Journal of Botany. 2006. 72 (2). 232-237. URL: https://doi.org/10.1016/j.sajb.2005.08.002. 
20. Michaelis M., Doerr H.W., Cinatl Jr J. Investigation of the influence of EPs ${ }^{\circledR} 7630$, a herbal drug preparation from Pelargonium sidoides, on replication of a broad panel of respiratory viruses. Phytomedicine. 2011. 18 (5). 384-386. URL: https://doi.org/10.1016/ j.phymed.2010.09.008.

21. Lizogub V.G., Riley D.S., Heger M. Efficacy of a pelargonium sidoides preparation in patients with the common cold: a randomized, double blind, placebo-controlled clinical trial. Explore. 2007. 3 (6). 573-584. URL: https://doi.org/10.1016/j.explore.2007.09.004.

22. Treatment of acute rhinosinusitis with the preparation from Pelargonium sidoides EPs 7630: a randomized, double-blind, placebocontrolled trial. Rhinology / C. Bachert et al. 2009. 47 (1). 51.

23. Pelargonium sidoides preparation $\left(\mathrm{EPs}^{\circledR} 7630\right)$ in the treatment of acute bronchitis in adults and children. Phytomedicine / H. Matthys et al. 2007. 14. 69-73. URL: https://doi.org/10.1016/j.phymed.2006. 11.015 .

24. Бережний В.В. Гострі респіраторні захворювання у дітей: ранній стартовий підхід до терапії. Доказова база даних (огляд). Современная педиатрия. 2019. № 1. C. 89-101. DOI 10.15574/ SP.2019.97.89.

25. Вплив лікарського засобу Резістол® на гуморальний та клітинний імунітет дітей з рекурентними та гострими вірусними респіраторними захворюваннями: результати дослідження. Современная педиатрия / Л.В. Квашніна. 2018. № 8. С. 104-113. DOI 10.15574/SP.2018.96.104.

26. Опыт использования препарата Резистол в комплексном лечении пациентов с острым бронхитом. Семейная медицина / М.Н. Селюк и др. 2015. № 3. С. 201-201.

27. Мироник О.В., Давиденко О.М., Фельдман Л.Я. Клінічна ефективність препарату «Папалор» в комплексному лікуванні хворих на ангіни. Pridneprovskiy scientific bulletin. 2015. № 40 (456). URL: http://rusnauka.com/index.php/rusnauka/article/view/22306.

28. Черных В.П., Георгиянц В.А., Зупанец И.А. Клиникофармацевтические аспекты применения фитопрепарата «Умкалор». Журнал вушних, носових і горлових хвороб. 2003. № 3. С. 74-83.

29. Ёлкина Т.Н., Грибанова О.А. Монотерапия острых респираторных инфекций препаратом «Умкалор». РМЖ. 2008. № 16 (29). 1968 c. 
30. Косаківський А.А., Безшапочний С.Б. Прогнозування «Умкалор» та «Цинабсин» при лікуванні хворих на гострий риносинуіт. ЖУНГ. 2010. № 6. С. 10-12.

31. Сайт Державної реєстрації лікарських засобів України. URL: http://www.drlz.com.ua.

32. Державна фармакопея України. Вид. 2-ге, перероб. та доп. Харків : Вид-во «Державне підприємство Український науковий фармакопейний центр якості лікарських засобів», 2011. 540 с.

\section{Information about the authors:}

Bryda O. R.,

Postgraduate Student at the Department of Technology of Biologically Active Substances, Pharmacy and Biotechnology Lviv Polytechnic National University 12, Bandera str., Lviv, 79000, Ukraine

Sradnytska N. Ye., Candidate of Chemical Science, Associate Professor at the Department of Technology of Biologically Active Substances, Pharmacy and Biotechnology Lviv Polytechnic National University 12, Bandera str., Lviv, 79000, Ukraine 